\begin{tabular}{|c|c|c|}
\hline \multirow{3}{*}{$\begin{array}{r}\text { Case Reports in } \\
\text { Gastroenterology }\end{array}$} & \multirow{2}{*}{\multicolumn{2}{|c|}{ Case Rep Gastroenterol 2014;8:377-380 }} \\
\hline & & \\
\hline & $\begin{array}{l}\text { DOI: 10.1159/000369966 } \\
\text { Published online: December 4, } 2014\end{array}$ & $\begin{array}{l}\text { ○ } 2014 \text { S. Karger AG, Basel } \\
\text { 1662-0631/14/0083-0377 } \$ 39.50 / 0 \\
\text { www.karger.com/crg }\end{array}$ \\
\hline & \multicolumn{2}{|c|}{$\begin{array}{l}\text { This is an Open Access article licensed under the terms of the Creative Commons } \\
\text { Attribution-NonCommercial } 3.0 \text { Unported license (CC BY-NC) (www.karger.com/OA } \\
\text { license), applicable to the online version of the article only. Distribution permitted for non } \\
\text { commercial purposes only. }\end{array}$} \\
\hline
\end{tabular}

\title{
Eosinophilic Jejunitis Presenting as Intractable Abdominal Pain
}

\author{
Zeynel Mungan ${ }^{a, b} \quad$ Tan Attila $^{a, b} \quad$ Yersu Kapran $^{c} \quad$ Ilyas Pinar Tokatli ${ }^{d}$ \\ Zeynep Unal ${ }^{\mathrm{e}}$ \\ a Department of Gastroenterology, Koc University School of Medicine, and Departments of \\ ${ }^{b}$ Gastroenterology, ${ }^{\mathrm{C}}$ Pathology, ${ }^{\mathrm{d}}$ Internal Medicine and ${ }^{\mathrm{e}}$ Diagnostic Radiology, American \\ Hospital, Istanbul, Turkey
}

\section{Key Words}

Eosinophilic jejunitis · Eosinophilic enteritis · Abdominal pain

\begin{abstract}
Eosinophilic gastroenteritis is an uncommon disease characterized by eosinophilic infiltration of the gastrointestinal tract. The clinical manifestations are related to the layer(s) and extent of the bowel involved. In this paper, we present a case of intractable abdominal pain caused by jejunal submucosal eosinophilic infiltration without mucosal involvement, diagnosed by deep endoscopic biopsies. The patient was successfully treated with steroids without need for surgery for diagnosis or therapy.

(c) 2014 S. Karger AG, Basel
\end{abstract}

\section{Introduction}

Eosinophilic gastroenteritis (EG) is a rare disorder that can present with various gastrointestinal manifestations, depending on the site and layer(s) of the gastrointestinal tract involved [1, 2]. Patients with mucosal layer involvement may present with dyspepsia, abdominal pain, diarrhea, iron deficiency anemia, malabsorption and protein-losing enteropathy. Patients with submucosal involvement may present with obstructive symptoms and may require surgery for treatment as well as diagnosis. Patients with serosal layer involvement may present with eosinophilic ascites. Although peripheral eosinophilia can be found in most of the patients, its presence is not necessary for diagnosis [1, 2]. The currently accepted criteria are the presence of gastrointestinal symptoms, a predominant eosinophilic infiltrate on histopathological examination and exclusion of other causes of eosinophilia

Zeynel Mungan, MD

Department of Gastroenterology, American Hospital

Guzelbahce Sokak, No 20, Nisantasi

TR-34365 Istanbul (Turkey)

E-Mail zmungan@ku.edu.tr 
Mungan et al.: Eosinophilic Jejunitis Presenting as Intractable Abdominal Pain

such as parasitic infections, inflammatory bowel disease, connective tissue disease, drug side effects and lymphoproliferative malignancies [3].

\section{Case Report}

A 53-year-old man presented to the emergency room with three episodes of severe and diffuse abdominal pain within a period 2 days. His past medical history was remarkable for diabetes mellitus which was controlled with metformin $850 \mathrm{mg}$ b.i.d. and glimepiride $1 \mathrm{mg}$ b.i.d. He had splenectomy secondary to trauma. He denied any associated change in bowel habits, nausea, vomiting, fever, rash or weight loss. He also denied any history of illicit drug use. He has no food, pollen or drug allergies. On physical examination, temperature was $36.7^{\circ} \mathrm{C}$, blood pressure was $120 / 80 \mathrm{~mm} \mathrm{Hg}$, pulse rate was $80 / \mathrm{min}$, respiration rate was $18 /$ min and BMI was 28 . The cardiac and pulmonary systems were unremarkable, and there was diffuse abdominal tenderness without guarding and rebound. Laboratory studies

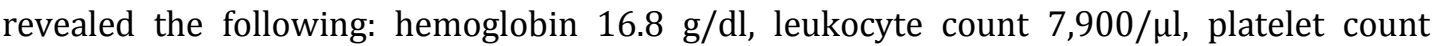

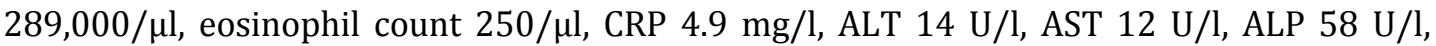
GGT $18 \mathrm{U} / \mathrm{l}$, total bilirubin $1.14 \mathrm{mg} / \mathrm{dl}$, lipase $51 \mathrm{U} / \mathrm{l}$, amylase $45 \mathrm{U} / \mathrm{l}$, creatinine $0.9 \mathrm{mg} / \mathrm{dl}$, CK $27 \mathrm{U} / \mathrm{l}, \mathrm{LDH} 130 \mathrm{U} / \mathrm{l}, \mathrm{K} 4.2 \mathrm{mmol} / \mathrm{l}, \mathrm{Na} 139 \mathrm{mmol} / \mathrm{l}$ and troponin I $0.001 \mathrm{ng} / \mathrm{ml}$. No ova/parasites were noted on repeated stool examinations. Abdominal X-ray and upper abdominal ultrasonography were normal.

Although the initial laboratory and imaging evaluation was unremarkable, abdominal computed tomography was performed due to persistent abdominal pain not controlled with narcotics, which revealed segmental jejunal wall thickening (fig. 1). Endoscopic examinations did not show any abnormality in the esophagus, stomach duodenum, terminal ileum and colon, with normal histopathological findings. At push endoscopy, the jejunal mucosa was normal. Deep biopsies were taken with bite-on-bite technique. Histopathological findings of jejunal biopsies showed dense submucosal eosinophilic infiltration (fig. 2). No parasites were noted on histopathological evaluation of biopsies as well as stool studies. Other causes of eosinophilic enteritis were excluded. Methylprednisolone $(32 \mathrm{mg} /$ day) was started. The patient had complete symptomatic recovery within a few days and was kept on the same dosage of steroids for 3 weeks. Steroids were subsequently tapered over the next 5 weeks. The patient has been asymptomatic for the last 2 months.

\section{Discussion}

EG is an uncommon inflammatory disease characterized by eosinophilic infiltration of the gastrointestinal tract [3]. About 300 cases have been reported since the first description of this disease by Kaijser in 1937 [3, 4]. The clinical features of EG are related to the layer(s) and extent of bowel affected by eosinophilic infiltration [2]. The prevalence of each subtype is unknown because of reporting and referral biases. Surgical series report a predominance of muscular disease with obstruction [5], while medical series primarily describe patients with mucosal involvement $[2,6]$. Serosal layer involvement is most rare, and mucosal involvement is most frequent $[2,7]$. The disease can affect patients of any age, but typical presentations are in the third through fifth decades, with a male predominance [2]. The diagnosis of EG is confirmed by a characteristic biopsy and/or eosinophilic ascitic fluid in the absence of infection by intestinal parasites or other causes of intestinal eosinophilia. The 
Mungan et al.: Eosinophilic Jejunitis Presenting as Intractable Abdominal Pain

long-term prognosis for patient with EG is generally favorable. Mortality related to the disease itself is rare. EG does not predispose patients to gastrointestinal malignancy [7].

Despite its rarity, EG needs to be recognized by the clinician because this treatable disease can be misdiagnosed as functional bowel disorder. In our case, functional abdominal pain was the initial working diagnosis in the setting of normal biochemical and sonographic evaluation, including no peripheral eosinophilia. However, intractability of abdominal pain led to a computed tomography scan which showed jejunal wall thickening, for which bite-onbite biopsies were obtained from normal-looking jejunal mucosa to evaluate infiltration of deeper layers. As in our case, mucosal and/or submucosal EG should be considered in the differential diagnosis of unexplained gastrointestinal symptoms, even in the absence of peripheral eosinophilia [2]. Peripheral eosinophilia can be a clue for EG in patients with unexplained abdominal pain. Almost three-quarters of EG cases have peripheral eosinophilia [2]. The biopsies from submucosal layers with bite-on-bite technique established the diagnosis. In cases of non-diagnostic biopsies, surgery with full-thickness biopsy is necessary to make the diagnosis.

Food intolerance or allergy has been reported in more than $50 \%$ of patients with mucosal EG. However, patients with submucosal and serosal eosinophilic infiltration do not show such an association [2]. This may be due to lack of exposure of luminal antigens to deeper intestinal layers, unless there is a mucosal break. In our case, there was no history of food intolerance/allergy, and involvement of EG was in the submucosal layer. No other causes of tissue eosinophilia were found. Parasites or ova were excluded repeatedly. The patient had a good symptomatic recovery with steroid therapy. Parasitosis must be excluded before steroid treatment because steroid treatment can lead to hyperinfection.

In conclusion, submucosal layer involvement of EG should be considered in the differential diagnosis of abdominal pain even without any biochemical abnormality. Even though the endoscopic mucosal appearance is normal, deeper endoscopic tissue sampling should be attempted in case of thickened intestinal wall on cross-sectional imaging. Steroids are the main treatment modality of this disease.

\section{References}

1 Agrawal N, Rani KU, Sridhar R, Dhamayanthi S: Eosinophilic gastroenteritis: a diagnosis behind the curtains. J Clin Diagn Res 2012;6:1789-1790.

-2 Talley NJ, Shorter RG, Phillips SF, Zinsmeister AR: Eosinophilic gastroenteritis: a clinicopathological study of patients with disease of mucosa, muscle and subserosal tissue. Gut 1990;31:54-58.

-3 Khan S: Eosinophilic gastroenteritis. Gastroenterol Clin North Am 2008;37:333-348.

4 Kaijser R: Zur Kenntnis der allergischen Affektionen des Verdauungskanals vom Standpunkt des Chirurgen aus. Arch Klin Chir 1937;188:36-64.

5 Yun MY, Cho YU, Park IS, Choi SK, Kim SJ, Shin SH, Kim KR: Eosinophilic gastroenteritis presenting as small bowel obstruction: a case report and review of the literature. World J Gastroenterol 2007;13:1758-1760.

-6 Chang JY, Choung RS, Lee RM, Locke GR 3rd, Schleck CD, Zinsmeister AR, Smyrk TC, Talley NJ: A shift in the clinical spectrum of eosinophilic gastroenteritis toward the mucosal disease type. Clin Gastroenterol Hepatol 2010;8:669-675.

7 Karande TT, Oak SN, Trivedi AA, Karmarkar SS, Kulkarni BB, Kalgutkar AA: Proximal jejunal obstruction due to eosinophilic gastroenteritis. J Postgrad Med 1996;42:121-123. 
Mungan et al.: Eosinophilic Jejunitis Presenting as Intractable Abdominal Pain

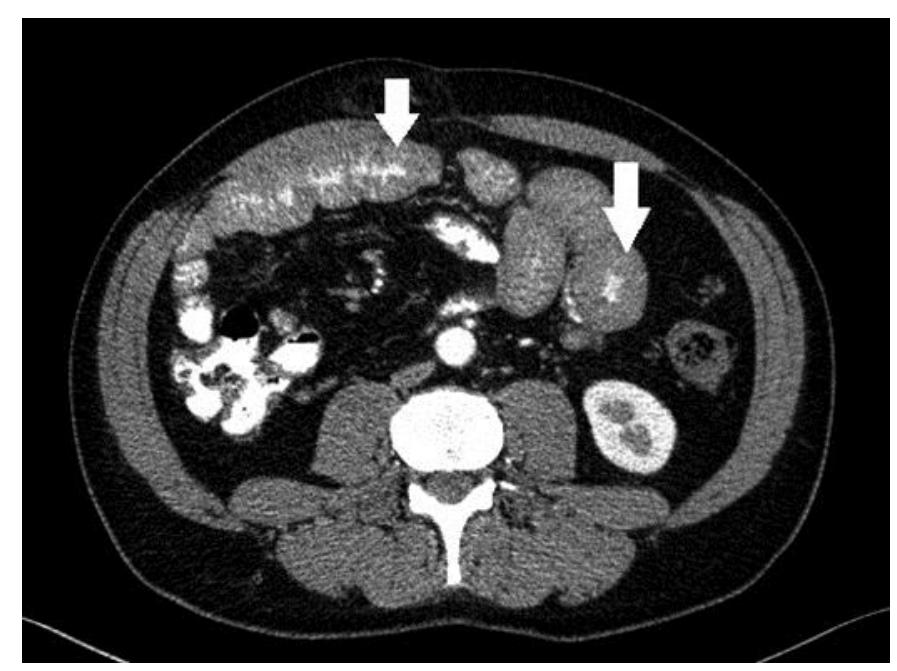

Fig. 1. Computed tomography revealing thickening of the jejunal wall (arrows).
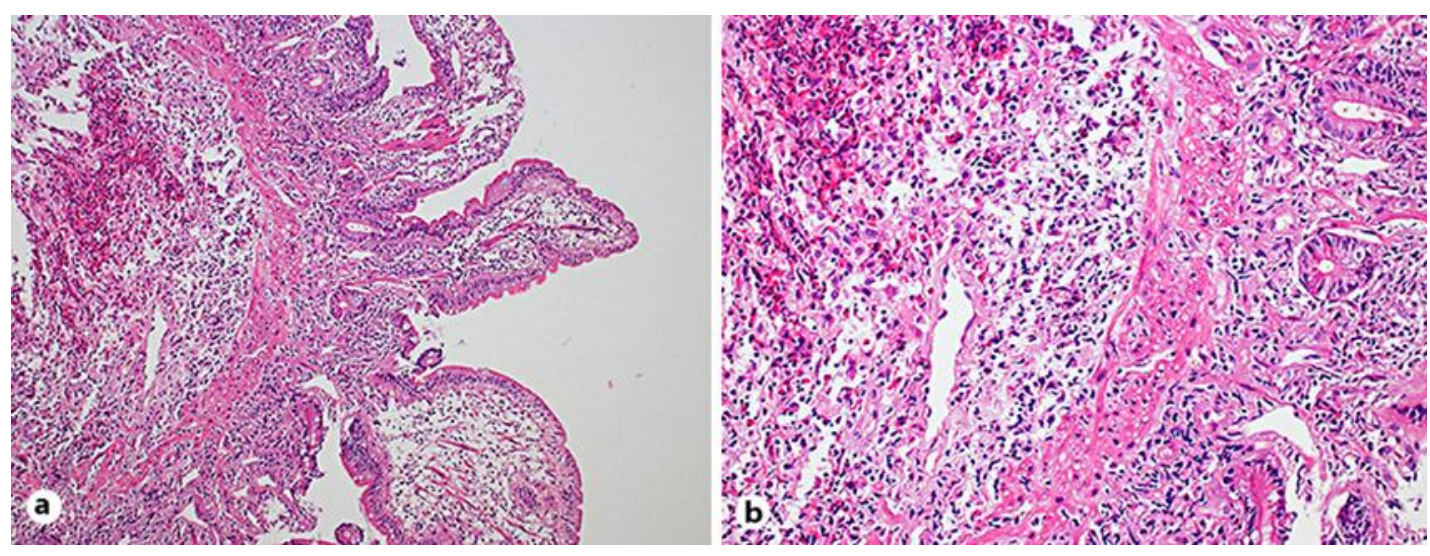

Fig. 2. Histopathological appearance of jejunal biopsy demonstrating infiltration with eosinophils in the submucosa (a HE, $\times 10$; b HE, $\times 20$ ). 